\title{
NOTE ON AN ABNORMAL SEEDLING OF WIDDRINGTONIA CUPRESSOIDES, AND A BRIEF ACCOUNT OF THE VASCULAR SYSTEM OF THE NORMAL SEEDLING.
}

By H. S. Morris. Communicated by E. P. Phillips, M.A.

(Read June 16, 1909.)

Among some seedlings of Widdringtonia cupressoides, Endl., * kindly germinated by Mr. G. H. Ridley, of the Municipal Gardens, Cape Town, for Mr. W. T. Saxton, of the South African College, who handed them over to me for investigation, was a curious example of incomplete twin formation. As far as the writer is aware, there is no other case on record of such an occurrence among Gymnosperms, although somewhat similar cases have been found among Dicotyledons.

This specimen (shown in Fig. 1) consisted of two seedlings fused together very completely throughout the length of the hypocotyl and the upper part of the root. The two root-tips were, however, separate and distinct, as were the two pairs of cotyledons and the plumules. In the fused part the cortical tissue of the two seedlings was continuous, and had a com-

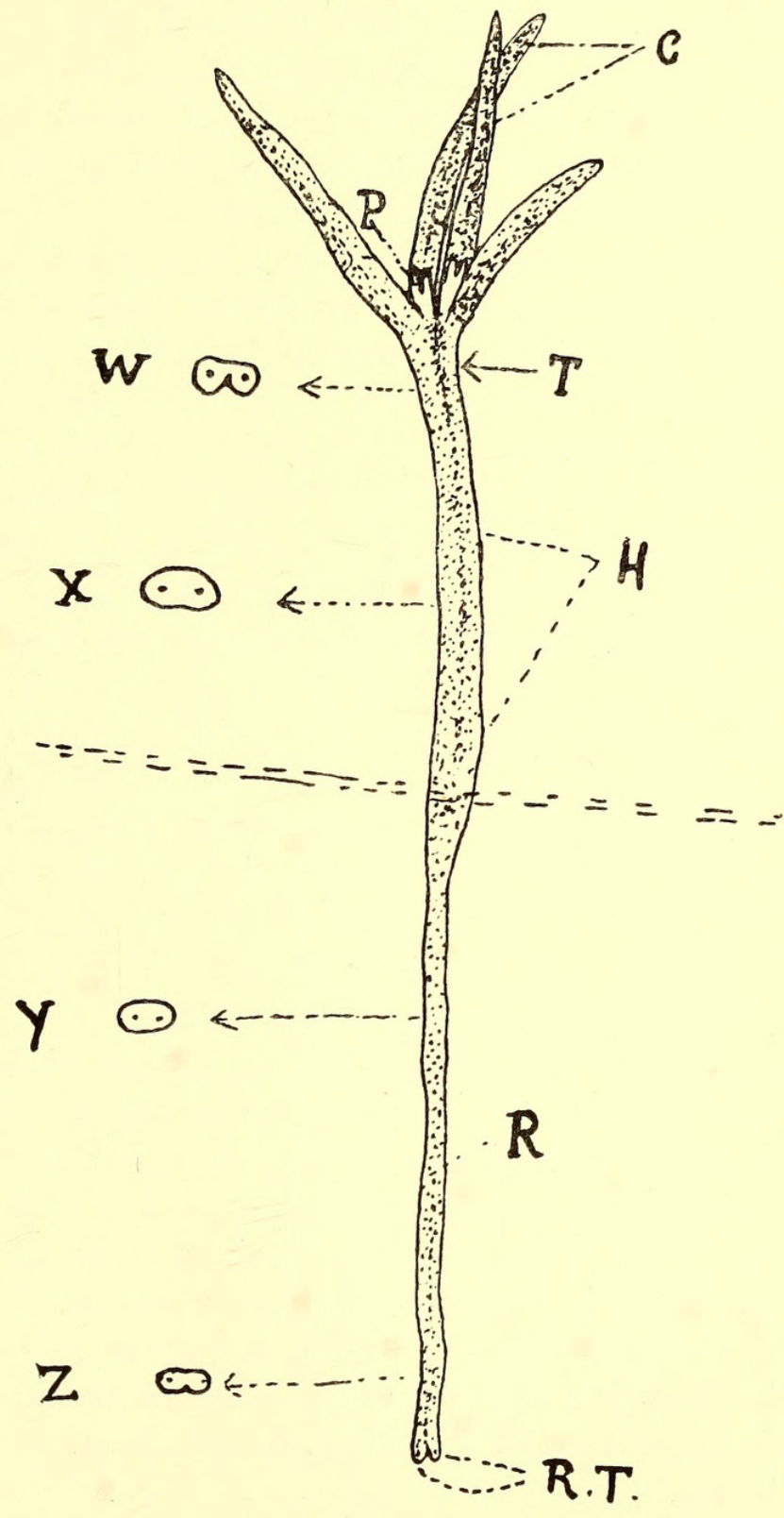

FIG. 1. $-\mathrm{C}=$ cotyledons $; \mathrm{P}=$ plumule $; \mathrm{T}=$ transition region ; $\mathrm{H}=$ hypocotyl $; \mathrm{R}=$ root ; $\mathrm{RT}=$ the two roottips; $\mathrm{W}, \mathrm{X}, \mathrm{Y}, \mathrm{Z}=$ successive transverse sections through regions indicated by arrows. (Natural size.)

* = Callitris cupressoides, Vent. 
mon epidermis. The two must therefore have been united from a very early period of development. As the two plants were so intimately bound together they probably arose from the same archegonium; each, possibly, from one of the two daughter nuclei resulting from the first division of the oospore.

Although the epidermis and the cortex were continuous, yet the vascular systems of the two halves were completely separate, as shown in Fig. 2. There was no difference between the vascular structure of the two parts, and each resembled exactly that of a normal seedling. Each part of the root showed the usual diarch structure, and the transition from stem to root structure was very rapid, taking place just below the insertion of the seed leaves.

In this seedling, and in two normal ones studied, the transition phenomena were different from those described for Widdringtonia mahoni, Mast., and W. whytei, Rendle, by Hill and de Fraine.* In Widdringtonia



FIG. 2.-X = xylem ; $\mathrm{P}=$ phloem $; \mathbf{C}=$ cortex; $\mathrm{E}=$ epidermis. The position of this section is shown by $\mathrm{W}$ in Fig. 1. $(\times 22$.

\section{diarch root.} the cotyledon was still entirely undivided when it reached the central cylinder of the hypocotyl. In this region the phloem forms a continuous ring, and the xylem of the seed-leaf traces becomes mesarch and finally exarch. When the latter condition obtains the phloem disappears opposite the two protoxylem groups, thus resulting in the typical

The splitting of the seed-leaf trace described by Hill and de Fraine (loc. cit.) for the two species mentioned above does not take place, nor does the transition from the hypocotyl to root in this species correspond exactly to that in any member of the Cupressineæ as described by these authors, more nearly approaching that in Cephalotaxus pedunculata, Sieb. and Zucc. This indicates a greater simplicity of structure in $W$. cupressoides than in the above-mentioned species.

In conclusion, I may state that these investigations were carried out in the Botanical Laboratory of the South African College, Cape Town, under the supervision of Mr. W. T. Saxton, M.A., to whom I wish to express my thanks.

* T. G. Hill and E. de Fraine (1908), "On the Seedling Structure of Gymnosperms," I. Ann. Bot. xxii., 88, 1908. 


\section{$2 \mathrm{BHL}$ Biodiversity Heritage Library}

Morris, H S and Phillips, E P. 1910. "NOTE ON AN ABNORMAL SEEDLING OF WIDDRINGTONIA CUPRESSOIDES, AND A BREIF ACCOUNT OF THE VASCULAR SYSTEM OF THE NORMAL SEEDLING." Transactions of the Royal Society of South Africa 1, 411-412. https://doi.org/10.1080/00359191009520052.

View This Item Online: https://www.biodiversitylibrary.org/item/181696

DOI: https://doi.org/10.1080/00359191009520052

Permalink: https://www.biodiversitylibrary.org/partpdf/175472

\section{Holding Institution}

Smithsonian Libraries

\section{Sponsored by}

Biodiversity Heritage Library

\section{Copyright \& Reuse}

Copyright Status: Not in copyright. The BHL knows of no copyright restrictions on this item.

This document was created from content at the Biodiversity Heritage Library, the world's largest open access digital library for biodiversity literature and archives. Visit BHL at https://www.biodiversitylibrary.org. 